\title{
Effect of lavender (Lavandula Stoechas) essential oil on growth performance, carcass characteristics, meat quality and antioxidant status of broilers
}

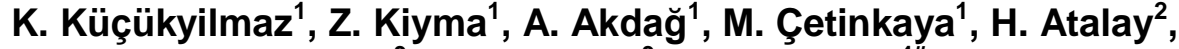 \\ A. Ateş ${ }^{3}$, F. E. Gürsel ${ }^{3} \&$ M. Bozkurt ${ }^{4 \#}$ \\ ${ }^{1}$ Department of Animal Science, Faculty of Agriculture, Eskisehir Osmangazi University, Eskisehir, Turkey \\ 2 Department of Animal Nutrition and Nutritional Diseases, Faculty of Veterinary Medicine, Balıkesir University, Balıkesir, \\ Turkey \\ ${ }^{3}$ Department of Biochemistry, Faculty of Veterinary Medicine, Istanbul University, Avcılar- Istanbul \\ ${ }^{4}$ Poultry Research Institute, Erbeyli, Aydın, Turkey
}

(Received 14 October 2016; Accepted 19 January 2017; First published online 8 February 2017)

Copyright resides with the authors in terms of the Creative Commons Attribution 4.0 South African License.
See: http://creativecommons.org/licenses/by/4.0/za
Condition of use: The user may copy, distribute, transmit and adapt the work, but must recognize the authors and the South African
Journal of Animal Science.

\begin{abstract}
The study evaluated the effect of essential oils from lavender (Lavandula stoaches) (LEO), on growth performance, carcass quality and antioxidant status of broilers. Three nutritionally adequate diets were composed with the addition of LEO at 0,24 , and $48 \mathrm{mg} / \mathrm{kg}$ of feed. The diets were fed as mash in the starter (d 0-21) and grower (d 22-39) phases. A total of 405 day-old chicks (Ross-308) were allocated to the three dietary treatments, each with three replicate pens with 45 birds per pen. After the first 21-day feeding period, the bodyweight of chicks fed $24 \mathrm{mg} / \mathrm{kg}$ LEO was higher $(P<0.01)$ than the $48 \mathrm{mg} / \mathrm{kg}$ LEO treatment, but only slightly higher than that of the untreated group. Diets with 24 and $48 \mathrm{mg} / \mathrm{kg}$ of LEO tended to increase final bodyweight of birds at 39 days old. No differences were observed for feed intake (FI), feed conversion ratio (FCR) and mortality among treatments. Feeding chickens on a diet with added LEO significantly reduced the relative weight of liver $(P<0.01)$ compared with the control $(\mathrm{CNT})$ group. Percentage of spleen weight of birds fed $24 \mathrm{mg} / \mathrm{kg}$ LEO was lower $(P<0.05)$ than for those who received $48 \mathrm{mg} / \mathrm{kg}$ LEO. However, it was similar to that of the CNT. Birds fed diets supplemented with 24 and $48 \mathrm{mg} / \mathrm{kg}$ LEO had breast meat with higher brightness ( $L^{*}$ value) and higher concentration of superoxide dismutase (SOD) compared with birds that did not receive LEO. Based on the data, it can be concluded that LEO could be used as a growth promoter in broiler nutrition with potential improvements in breast meat quality.
\end{abstract}

Keywords: Antioxidative activity, broiler, growth promoting effects, lavender oil, meat yield,

"Corresponding author: mehmetbozkurt9@hotmail.com, kamilk@ogu.edu.tr

\section{Introduction}

From the beginning of 2016, the use of antibiotic growth promoters (AGPs) in poultry diets has been banned in European Union (EU) countries because of resistance to pathogenic microorganisms and some residues in food products. Hence, research into alternatives to AGPs has gained importance to ensure animal health and performance without compromising human health (Steiner, 2009; Franz et al., 2010). In this respect, aromatic herbs, such as oregano, rosemary, sage mint, laurel, and their extracts and essential oils (EOs) are listed among the most commonly researched phytoadditives in broilers, all of which belong to the plant family of Labiate (Brenes \& Roura, 2010; Zeng et al., 2015). A sufficient number of studies have demonstrated that phytogenic products derived from these plants contain phenols and polyphenols as key constituents, which have multiple functions as a whole, including antimicrobial, antioxidant, anti-coccidial, immunomodulator activities, and digestion-enhancing properties (Dang et al., 2001; Jamroz et al., 2005; Basmacıoğlu et al., 2004; 2010; Jang et al., 2007; Bozkurt et al., 2012a; 2012b).

Scientific evidence involving EOs of oregano, rosemary and sage has demonstrated that they were able to reduce oxidative damage of fats in serum and edible tissues, with improvements in sensory and physical characteristics of poultry meat, particularly broiler chickens (Basmacıoğlu et al., 2004; Botsoglou et al., 2002; 2004). Despite the exhaustive investigations and efforts at in-depth characterization of the phenolic compounds derived from plants belonging to the Labiate family, knowledge of the mode of action and application with lavender is still rudimentary. 
Lavenders (Lavandula spp.) belong to the family Labiatae (Lamiacae) and have been used in dried form or as an EO for centuries for a variety of therapeutic and cosmetic purposes, including antibacterial, antifungal and anti-depressive uses. LEO has a complex structure with over 150 active constituents, including camphor, linalool, linalyl acetate, 1,8-cineole, $\beta$-cymene and terpinen-4-ol as the main components (Cavanagh \& Wilkinson, 2002). From various in vitro methods it has been established that LEO has a powerful antioxidant activity, which is attributed in particular to the presence of phenolic and polyphenolic substances (Gülçin et al., 2004). EOs from the Lavandula stoechas L. ssp. in Turkey contain more than $40 \%$ camphor (the main active component) which is characterized by antibacterial and antioxidant properties (Economou et al., 1991; Cowan, 1999; Öztürk et al., 2005).

Poultry meat is susceptible to oxidative deterioration owing to its phospholipid content (Halliwell \& Chirico, 1993), which contributes a robust response to the lipid antioxidant status of chicken meat. This could be generated by dietary supplementation of phytogenic compounds such as phenols by LEO in the present study. There are no scientific reports about the dietary supplemental effect of lavender (Lavandula stoaches) on the antioxidant status of chicken meat or broiler performance response. The authors considered that the well-documented antioxidative and antimicrobial properties of the phenolic compounds of LEO might have implications on growth performance, carcass characteristics and meat quality in broiler chickens. Therefore, the present study was conducted to assess the in-feed use of LEO (24 and $48 \mathrm{mg} / \mathrm{kg}$ diet) on growth performance, carcass characteristics, and meat quality aspects in broiler chickens reared up to 39 days old.

\section{Material and Methods}

All of the procedures for animal handling and sample collection were approved by Eskişehir

Osmangazi University Local Ethics Committee of Animal Experiments (HAYDEK-420-2014).

A total of 405 day-old sexed broiler chicks (Ross-308) (with bodyweight of $49.2 \pm 1.08 \mathrm{~g}$ ) from a commercial hatchery were divided into three treatment groups. Each group contained 135 birds and were randomly assigned to a treatment. The experiment was performed as a completely randomized design. Each treatment group was further sub-divided into three replicates containing 45 birds ( 22 males and 23 females). Each replicate was assigned to a clean floor pen $(2.3 \times 1.5 \mathrm{~m})$ equipped with one hanging bell drinker, two tube-type feeders, and electrical heaters. Birds were reared in pens ( 13 birds per $\mathrm{m}^{2}$ floor space) provided with litter (pine wood shavings) to a depth of 5-6 cm. The pen was the experimental unit (replicate) in the present study. The room temperature was gradually decreased from $33^{\circ} \mathrm{C}$ on chick arrival to $23^{\circ} \mathrm{C}$ on day 22, and then kept constant until trial termination on day 39. Chicks received 23 hours light/day during the experiment. The house was ventilated with adjustable windows. Birds were vaccinated against infectious bursal disease and Newcastle disease virus via drinking water at 10 and 14 days old, respectively.

The diet was a typical corn-wheat-soybean mixture, which was formulated to meet or exceed all nutrient recommendations in the Ross rearing guidelines (Aviagen, 2007) and did not contain AGPS or other performance enhancers. The diet, in mash form, and water were provided ad libitum. The chemical compositions of diets were determined according to the methods of AOAC (1990). Metabolic energy was calculated according to the Turkish Standards Institute (TSE) (1991). Starter and grower diets were given to broiler chickens during the experimental periods from days 1 to 21 and from days 22 to 39, respectively. Ingredients and nutritional composition of the starter and grower diets are presented in Table 1.

The first treatment group of the experiment was CNT, the feed of which consisted of corn, wheat and soybean (Table 1). The feeds of the second and third groups contained LEO derived from the selected herb (Lavandula stoaches), which grows wild in Turkey. The LEO was obtained by the water vapour distillation method provided by Inan Agriculture (Aksu-Antalya). The active compounds of the LEO were determined with the Gas Chromatography-Mass Spectrometry (HP 6890 GC/5973 MSD) system (Table 2). LEO was diluted with $\mathrm{n}$-hexane $(1: 100)$ and injected into the system (injection temperature $250{ }^{\circ} \mathrm{C}$; injection split 1/100; column DB-17 $30 \mathrm{~m}, 0.25 \mu \mathrm{m}, 0.32 \mathrm{~mm}$ (agilent); initial oven temperature $70{ }^{\circ} \mathrm{C}$, at a rate of $8{ }^{\circ} \mathrm{C} / \mathrm{min}$; final oven temperature $200{ }^{\circ} \mathrm{C}$; injection volume $1 \mu \mathrm{l}$ ).

Feed additive was prepared by infusing the determined ratio of the LEO to zeolite. The amount of LEO supplemented in each $1 \mathrm{~kg}$ feed for the second and third groups was $24 \mathrm{mg}$ and $48 \mathrm{mg}$, respectively. These dietary inclusion levels were based on the supplemental dosages of EOs of the Labiatae family in previous studies (Alçiçek et al., 2004; Bozkurt et al. 2012a), which demonstrated significant growth promoter efficacy. One $\mathrm{kg}$ feed additive was prepared by infusing $24 \mathrm{~g}$ and $48 \mathrm{~g}$ EO to $976 \mathrm{~g}$ and $952 \mathrm{~g}$ zeolite, respectively.

All chicks were weighed individually at days 1,21 , and 39 to determine bodyweight. Bodyweight gain was calculated for the related periods. FI in each subgroup was determined at days 21 and 39 . The FCR was calculated as the ratio of $\mathrm{Fl}$ to bodyweight gain ( $\mathrm{g}$ feed/g gain) on a replicate basis. Mortality was recorded daily for each subgroup, and calculated as the percentage of deaths to the initial number of chickens. 
Table 1 Ingredients and chemical composition of the starter and grower diets (as fed)

\begin{tabular}{|c|c|c|}
\hline Ingredients $(\mathrm{g} / \mathrm{kg})$ & Broiler starter diet $(\mathrm{g} / \mathrm{kg})$ & Broiler grower diet $(\mathrm{g} / \mathrm{kg})$ \\
\hline Corn & 368.00 & 420.00 \\
\hline Wheat & 200.00 & 200.00 \\
\hline Soybean meal & 355.00 & 300.00 \\
\hline Vegetable oil & 35.00 & 45.00 \\
\hline Limestone & 16.00 & 10.00 \\
\hline Dicalcium phosphate & 18.00 & 16.50 \\
\hline Sodium chloride & 2.50 & 3.50 \\
\hline Vitamin-mineral premix ${ }^{1}$ & 2.50 & 2.50 \\
\hline Methionine & 2.00 & 2.50 \\
\hline \multicolumn{3}{|l|}{ Chemical analyses (\%) } \\
\hline Dry matter & 88.22 & 88.11 \\
\hline Crude protein & 22.00 & 20.74 \\
\hline M.E. $(\mathrm{kcal} / \mathrm{kg})^{2}$ & 3050 & 3200 \\
\hline Crude oil & 4.77 & 5.90 \\
\hline Crude fibre & 2.58 & 2.44 \\
\hline Crude ash & 6.64 & 5.88 \\
\hline Calcium & 1.30 & 1.19 \\
\hline Available $\mathrm{P}^{2}$ & 0.46 & 0.40 \\
\hline
\end{tabular}

\footnotetext{
'Vitamin and mineral mix provided the following (per $\mathrm{kg}$ of diet): trans-retinol (vit. A) $3.6 \mathrm{mg}$; cholecalciferol (vit. $\mathrm{D}_{3}$ ) $0.1 \mathrm{mg}$; $\alpha$-tocopherol acetate (Vit. E) $75 \mathrm{mg}$; menadione (vit. $\left.\mathrm{K}_{3}\right) 5 \mathrm{mg}$; thiamine (vit. $\mathrm{B}_{1}$ ) $3 \mathrm{mg}$; riboflavin (vit. $\mathrm{B}_{2}$ ) $6 \mathrm{mg}$; pyridoxine (vit. $\left.\mathrm{B}_{6}\right) 5 \mathrm{mg}$; cyanocobolamin (vit. $\mathrm{B}_{12}$ ) $0.03 \mathrm{mg}$; nicotinic acid $40 \mathrm{mg}$; pantothenic acid $10 \mathrm{mg}$; folic acid 0.75 $\mathrm{mg}$; D-biotin $0.075 \mathrm{mg}$; choline chloride $375 \mathrm{mg}, 80 \mathrm{mg}$ of manganese $\left(\mathrm{MnSO}_{4} \cdot \mathrm{H}_{2} \mathrm{O}\right) ; 40 \mathrm{mg}$ of iron $\left(\mathrm{FeSO}_{4} \cdot 7 \mathrm{H}_{2} \mathrm{O}\right) ; 60$ $\mathrm{mg}$ of zinc ( $\mathrm{ZnO}) ; 5 \mathrm{mg}$ of copper ( $\left.\mathrm{CuSO}_{4} \cdot 5 \mathrm{H}_{2} \mathrm{O}\right) ; 0.15 \mathrm{mg}$ of iodine (ethylene diamine dihydroiodide); $0.3 \mathrm{mg}$ of selenium $\left(\mathrm{NaSeO}_{3}\right) .{ }^{2}$ Calculated values
}

Broilers were all slaughtered at 39 days of age. To determine the carcass yield, relative weight of the carcass cuts, internal organ weight, and meat quality characteristics, 16 birds (three males and three females from two of the three replicate pens and two male and two females from the third replicate), representing the average weight of the group ( $\pm 5 \%$ ), were selected from each group. Thus, 8 male and 8 female birds were sampled per treatment group. Then, 48 sampled birds were slaughtered by severing the jugular vein in the experimental processing unit $8 \mathrm{~h}$ after the feed withdrawal. The carcasses were immersed into hot water $\left(60{ }^{\circ} \mathrm{C}\right.$ for $\left.62 \mathrm{~s}\right)$, plucked and eviscerated manually. The whole carcass was weighed immediately and cut into parts. Hot carcass yield was calculated as a percentage of pre-slaughter live bodyweight. The breasts (including pectoralis major and pectoralis minor), legs (including thigh and drumstick), wings, and back were weighed. The percentage weight of the eviscerated carcasses was calculated as the ratio between the eviscerated carcass and live bodyweight. The percentages of the breast, leg, wing and back were calculated in relation to the eviscerated carcass weight. The weights of selected internal organs (gizzard, liver, spleen and pancreas) and abdominal fat were weighed and expressed as percentage of live bodyweight.

The breast and thighs were separated with their skin on. The colour values of these samples were determined according to the CIELAB method using Minolta CR-300 (USA) colorimeter apparatus. Lightness, redness, and yellowness values, $L^{*}, a^{*}$, and $b^{*}$, respectively, were represented according to this method. Water-holding capacity was measured by the centrifuging method (Castellini et al., 2002). Drip loss percentage was determined as described by Fanatico et al. (2005).

Tissue samples were washed in an ice-cold $20 \mathrm{mM}$ Tris- $\mathrm{HCl}(\mathrm{pH} \mathrm{7.4)}$ buffer solution, which contained $140 \mathrm{mM} \mathrm{KCl}$, and were homogenized in a $10 \mathrm{w} / \mathrm{v}$ ratio of the same buffer solution with a Teflon homogenizer (Miccra D-1, ART Prozess \& Labortechnik GmbH, Germany). Homogenates were centrifuged at $20000 \mathrm{~g}$ and $4{ }^{\circ} \mathrm{C}$ for $10 \mathrm{~min}$, and supernatants were separated. Products of lipid peroxidation were estimated by 
measuring the concentration of malondialdehyde (MDA), expressed as thiobarbituric acid-reactive substances according to the method of Yoshoiko (1979).

Table 2 Bioactive components of lavender essential oil

\begin{tabular}{lc}
\hline Component & $\%$ \\
\hline Camphor & 63.24 \\
Tenchone & 29.48 \\
Bornyl acetate & 1.49 \\
a-cadinol & 1.33 \\
Verbenone & 0.82 \\
Sabinene & 0.63 \\
Myrtenol & 0.54 \\
3-carene & 0.51 \\
Limonene & 0.44 \\
Campholene aldehyde & 0.31 \\
Tenchyl acetate & 0.28 \\
D-fenchly alcohol & 0.21 \\
$p$-cymene -8-ol & 0.17 \\
1,3,8-p- menthatriene & 0.16 \\
Eucalyptol & 0.14 \\
Trans-caryophyllene & 0.14 \\
Cis- $\beta$-terpineol & 0.11 \\
\hline
\end{tabular}

Total SOD activity was analysed according to the method of Sun et al. (1988) with a slight modification by Durak et al. (1993), based on the inhibition of nitroblue tetrazolium reduction by the xanthine/xanthine oxidase system as a superoxide generator. Catalase (CAT) activity was determined by measuring the decomposition of hydrogen peroxide according to the method of Aebi (1983) and was expressed as k/g protein, where $\mathrm{k}$ is the first-order rate constant. Contents of protein were measured in the homogenates according to the method of Lowry et al. (1951) using bovine serum albumin as the standard.

Data were analysed by ANOVA using the GLM procedure of SAS (2001). An arc-sin transformation was applied to the percentage values (i.e. mortality) before testing for differences. Significant differences among means of treatments were determined by Duncan's multiple range test with $5 \%$ probability.

\section{Results}

Data regarding performance indices during the starter phase ( 0 to $21 \mathrm{~d}$ ) and the overall growth period $(1$ to $39 \mathrm{~d})$ are presented in Table 3. During the starter phase ( 0 to 21), there were no significant differences $(P>0.05)$ in growth performance responses (i.e. BW, FI and FCR) between the CNT and 24 or $48 \mathrm{mg} / \mathrm{kg}$ LEO treatments. However, BW of chicks fed $24 \mathrm{mg} / \mathrm{kg}$ LEO was heavier $(P<0.01)$ than those treated with $48 \mathrm{mg} / \mathrm{kg}$ LEO. The supplementation diet with 24 and $48 \mathrm{mg} / \mathrm{kg}$ LEO had no significant effect on the BW, FI and FCR of chicks when compared with the CNT treatment during the study. In contrast to the pattern observed for $\mathrm{d} 0$ to 21 , chickens fed 24 and $48 \mathrm{mg} / \mathrm{kg}$ LEO had heavier BW than those in the untreated CNT group between $d 1$ and $d 39(P=0.09)$. The birds were in good health throughout the study. Therefore, the mortality rate of birds was not affected by dietary LEO supplementation throughout the experimental period.

Carcass yield and relative weights of carcass parts of broilers were unaffected by LEO supplementation $(P>0.05)$ (Table 4). Measurements of proportional weight of visceral organs and abdominal fat are shown in Table 5. The relative weights of the gizzard and pancreas were not affected by the dietary LEO supplementation $(P>0.05)$, whereas the relative weights of the liver and spleen were altered by LEO treatments. 
Table 3 Effects of dietary supplementation of lavender essential oil on growth performance of broiler chickens for the periods of $0-21$ days and 0-39 days

\begin{tabular}{|c|c|c|c|c|c|c|c|c|}
\hline \multirow[b]{2}{*}{$\operatorname{Diet}^{1}$} & \multicolumn{4}{|c|}{$0-21$ days } & \multicolumn{4}{|c|}{ 0-39 days } \\
\hline & $\begin{array}{c}\text { Body } \\
\text { weight }(g)\end{array}$ & $\begin{array}{c}\text { Feed } \\
\text { consumption } \\
\text { (g) }\end{array}$ & $\mathrm{FCR}^{3}$ & $\begin{array}{c}\text { Mortality } \\
(\%)\end{array}$ & $\begin{array}{c}\text { Body } \\
\text { weight (g) }\end{array}$ & $\begin{array}{c}\text { Feed } \\
\text { consumption (g) }\end{array}$ & $\mathrm{FCR}^{3}$ & $\begin{array}{c}\text { Mortality } \\
(\%)\end{array}$ \\
\hline CNT & $994^{\mathrm{ab}}$ & 1412 & 1.494 & 1.33 & 2607 & 4672 & 1.826 & 1.33 \\
\hline LEO-24 & $1013^{a}$ & 1434 & 1.487 & 3.53 & 2654 & 4637 & 1.795 & 3.53 \\
\hline LEO-48 & $973^{b}$ & 1400 & 1.526 & 2.93 & 2690 & 4693 & 1.788 & 2.93 \\
\hline SEM $^{2}$ & 9.66 & 16.3 & 0.028 & 1.21 & 30.84 & 70.6 & 0.024 & 1.21 \\
\hline$P$ value & 0.0182 & 0.3887 & 0.6134 & 0.4658 & 0.0942 & 0.8554 & 0.5477 & 0.4658 \\
\hline
\end{tabular}

\footnotetext{
${ }^{a, b}$ Values within a column that do not share the same superscript are different at $P<0.05$

${ }^{1}$ The broilers were fed a control diet (CNT) that contained no anticoccidial or performance enhancer or a diet supplemented with $24 \mathrm{mg} / \mathrm{kg}$ (LEO-24) and $48 \mathrm{mg} / \mathrm{kg}$ (LEO-48) of lavender essential oil (LEO)

${ }^{2}$ Data are means of three replicate pens with 135 chicks each per treatment

FCR3: Feed Conversion Ratio (g feed/g gain)
}

Table 4 Effects of dietary administration with $24 \mathrm{mg} / \mathrm{kg}$ and $48 \mathrm{mg} / \mathrm{kg}$ lavender essential oil on carcass dressing percentage and carcass cut-up yields of chickens slaughtered at 39 days old age

\begin{tabular}{|c|c|c|c|c|c|}
\hline $\operatorname{Diet}^{1}$ & Carcass yield (\%) & Thigh (\%) & Breast (\%) & Wing (\%) & Back (\%) \\
\hline CNT & 75.95 & 27.70 & 38.84 & 9.49 & 23.96 \\
\hline LEO-24 & 75.00 & 27.69 & 38.76 & 9.89 & 23.27 \\
\hline LEO-48 & 75.21 & 28.11 & 39.26 & 9.72 & 22.64 \\
\hline SEM $^{2}$ & 0.34 & 0.35 & 0.44 & 0.15 & 0.36 \\
\hline$P$ value & 0.2021 & 0.6543 & 0.7036 & 0.1988 & 0.0607 \\
\hline
\end{tabular}

\footnotetext{
${ }^{a, b}$ Values within a column that do not share the same superscript are different at $P<0.05$

${ }^{1}$ The broilers were fed a control diet (CNT) that contained no anticoccidial or performance enhancer or a diet supplemented with $24 \mathrm{mg} / \mathrm{kg}$ (LEO-24) and $48 \mathrm{mg} / \mathrm{kg}$ (LEO-48) of lavender essential oil (LEO)

${ }^{2}$ Data are means of 16 measurements each per treatment
}

Table 5 Relative weight (\%) of visceral organs and abdominal fat pad in broilers administered with lavender essential oil for 39 day-feeding period

\begin{tabular}{lccccc}
\hline Diet $^{1}$ & Gizzard & Liver & Spleen & Pancreas & Abdominal Fat \\
\hline CNT & 1.33 & $1.94^{\mathrm{a}}$ & $0.085^{\mathrm{ab}}$ & 0.186 & 0.010 \\
LEO-24 & 1.29 & $1.71^{\mathrm{b}}$ & $0.077^{\mathrm{b}}$ & 0.190 & 0.014 \\
LEO-48 & 1.24 & $1.80^{\mathrm{b}}$ & $0.091^{\mathrm{a}}$ & 0.185 & 0.011 \\
SEM $^{2}$ & 0.03 & 0.04 & 0.04 & 0.007 & 0.001 \\
P value & 0.2048 & 0.0043 & 0.0477 & 0.8610 & 0.0603
\end{tabular}

\footnotetext{
${ }^{\mathrm{a}, \mathrm{b}}$ Values within a column that do not share the same superscript are different at $P<0.05$

${ }^{1}$ The broilers were fed a control diet (CNT), which contained no anticoccidial or performance enhancer or a diet supplemented with $24 \mathrm{mg} / \mathrm{kg}$ (LEO-24) and $48 \mathrm{mg} / \mathrm{kg}$ (LEO-48) of lavender essential oil (LEO)

${ }^{2}$ Data are means of 16 measurements each per treatment.
}

Feeding chickens a diet with LEO reduced the relative weight of liver compared with those of the untreated CNT group $(P<0.01)$. The percentage weight of spleen of birds fed $24 \mathrm{mg} / \mathrm{kg}$ LEO was lower $(P$ 
$<0.05)$ than those that received $48 \mathrm{mg} / \mathrm{kg}$ LEO, and no differences were observed between the CNT and treated groups.

Meat colour $\left(L^{*}, a^{*}, b^{*}\right.$ colour values), water-holding capacity, and drip loss of breast and thigh meat of chickens fed a diet with or without LEO are presented in Table 6 . There were no treatment differences $(P$ $>0.05)$ in meat quality characteristics, with the exception of the breast meat $L^{*}$ value of chicks. Birds treated with LEO had a higher $L^{*}$ value $(P<0.01)$ than those on a diet without LEO.

Table 6 Effects of lavender essential oil supplementation on colour ( $L^{*}$, $a^{*}$ and $b^{*}$ values), drip loss and water holding capacity in thigh and breast meat of broilers measured at day 39

\begin{tabular}{|c|c|c|c|c|c|c|c|c|c|c|}
\hline \multirow{2}{*}{$\operatorname{Diet}^{1}$} & \multicolumn{5}{|c|}{ Thigh meat } & \multicolumn{5}{|c|}{ Breast meat } \\
\hline & $L^{*}$ & $a^{*}$ & $b^{*}$ & $\mathrm{WHC}^{3}$ & $\mathrm{DL}^{4}$ & $\mathrm{~L}^{*}$ & $a^{*}$ & $b^{*}$ & $\mathrm{WHC}^{3}$ & $\mathrm{DL}^{4}$ \\
\hline CNT & 59.9 & 8.05 & 8.20 & 65.6 & 0.667 & $56.29^{b}$ & 8.57 & 8.36 & 58.4 & 1.75 \\
\hline LEO-24 & 58.8 & 7.40 & 8.39 & 65.5 & 0.608 & $58.49^{a}$ & 7.98 & 8.61 & 58.4 & 1.87 \\
\hline LEO-48 & 58.4 & 7.97 & 8.53 & 65.1 & 0.632 & $58.38^{\mathrm{a}}$ & 7.93 & 7.99 & 57.9 & 2.08 \\
\hline $\mathrm{SEM}^{2}$ & 0.73 & 0.50 & 0.29 & 0.67 & 0.053 & 0.61 & 0.47 & 0.22 & 0.61 & 0.17 \\
\hline$P$ value & 0.0965 & 0.6169 & 0.7316 & 0.8223 & 0.7403 & 0.0233 & 0.0898 & 0.0818 & 0.7908 & 0.4000 \\
\hline
\end{tabular}

${ }^{\mathrm{a}, \mathrm{b}}$ Values within a column that do not share the same superscript are different at $P<0.05$

${ }^{1}$ The broilers were fed a control diet (CNT) that contained no anticoccidial or performance enhancer or a diet supplemented with $24 \mathrm{mg} / \mathrm{kg}$ (LEO-24) and $48 \mathrm{mg} / \mathrm{kg}$ (LEO-48) of lavender essential oil (LEO)

${ }^{2}$ Data are means of 16 measurements each per treatment.

${ }^{3} \mathrm{WHC}=$ Water holding capacity ; ${ }^{4} \mathrm{DL}=$ Drip Loss

The effects of LEO on MDA, superoxide dismutase (SOD), and catalase (CAT) concentrations in blood serum, breast meat and liver of chickens are shown in Table 7. The results of this study showed that there were no significant differences $(P>0.05)$ in MDA, SOD and CAT concentrations in blood serum, breast meat, and liver, with the exception of the SOD concentration of breast meat $(P>0.05)$. Dietary LEO supplementation significantly increased SOD concentration of breast meat $(P<0.05)$.

Table 7 The influence of dietary supplementation with lavender essential oil on malondialdehyde, superoxide dismutase, and catalase concentrations in blood serum, breast meat and liver of chickens

\begin{tabular}{lccccccccc}
\hline \multirow{2}{*}{ Diet $^{1}$} & \multicolumn{3}{c}{$\mathrm{MDA}^{3}(\mu \mathrm{mol} / \mathrm{L})$} & \multicolumn{3}{c}{$\mathrm{SOD}^{4}$ (Inhibition \%) } & \multicolumn{3}{c}{$\mathrm{CAT}^{5}(\mathrm{mmol} \mathrm{U} / \mathrm{mL})$} \\
\cline { 2 - 10 } & Serum & Meat & Liver & Serum & Meat & Liver & Serum & Meat & Liver \\
\hline CNT & 11.6 & 12.1 & 14.0 & 74.6 & $60.2^{\mathrm{b}}$ & 53.9 & 68.4 & 59.3 & 71.8 \\
LEO-24 & 12.0 & 13.4 & 16.8 & 73.1 & $69.4^{\mathrm{a}}$ & 51.0 & 58.6 & 66.9 & 83.0 \\
LEO-48 & 11.3 & 13.8 & 16.7 & 72.7 & $67.7^{\mathrm{a}}$ & 55.8 & 51.0 & 51.5 & 54.4 \\
SEM $^{2}$ & 1.63 & 2.72 & 2.08 & 4.41 & 2.54 & 3.3 & 7.20 & 6.74 & 9.69 \\
P value $^{0.9620}$ & 0.8887 & 0.1004 & 0.9496 & 0.0406 & 0.5508 & 0.1931 & 0.2670 & 0.0989
\end{tabular}

\footnotetext{
${ }^{a, b}$ Values within a column not sharing the same superscript are different at $P<0.05$

${ }^{1}$ The broilers were fed a control diet (CNT) that contained no anticoccidial or performance enhancer or a diet supplemented with $24 \mathrm{mg} / \mathrm{kg}$ (LEO-24) and $48 \mathrm{mg} / \mathrm{kg}$ (LEO-48) of lavender essential oil (LEO)

${ }^{2}$ Data are means of 16 measurements each per treatment

$\mathrm{MDA}^{3}=$ Malondialdehyde; $\mathrm{SOD}^{4}=$ Superoxide dismutase; $\mathrm{CAT}^{5}=$ Catalase
}

\section{Discussion}

The present study was conducted to compare the effects of LEO as a source of phytoadditive when fed to broiler chickens at levels of 24 and $48 \mathrm{mg} / \mathrm{kg}$ diet on performance, carcass yield and meat quality features, including sensory characteristics and oxidative stability. LEO supplementation at $24 \mathrm{mg} / \mathrm{kg}$ tended to increase the BW of broilers after 21 days feeding period, but feeding on $48 \mathrm{mg} / \mathrm{kg} \mathrm{LEO} \mathrm{showed} \mathrm{no} \mathrm{such}$ 
beneficial effect. However, broilers fed diets supplemented with 24 and $48 \mathrm{mg} / \mathrm{kg}$ had slight increases $(P=$ 0.09 ) in bodyweight at d 39 compared with those fed no LEO. Such increase of bodyweight as 47 and $83 \mathrm{~g}$ in birds fed 24 and $48 \mathrm{mg} / \mathrm{kg}$ LEO without consuming extra feed could be regarded as growth promotion. It is reasonable to expect such an effect by LEO because of its well-documented antimicrobial and antioxidant effects (Economou et al. 1991, Cowan, 1999; Gülçin et al 2004) and the probable digestive enhancer activity of phenolic compounds (Jamroz et al. 2005; Basmacıoğlu et al. 2010), which is a core mode of beneficial nutritional action. The results for bodyweight gain are similar to the findings of earlier studies on supplementing broiler diets with EOs of oregano, rosemary, sage and lavender, all of which belong to the Labiate plant family and contain phenols as key components (Alçiçek et al., 2003; Alçiçek et al., 2004;, Basmacıoğlu et al., 2004; Basmacıoğlu et al., 2010; Botsoglou et al., 2004; Hernandez et al., 2004; Bozkurt et al., 2009; Bozkurt et al., 2012a; b).

No differences were observed in $\mathrm{Fl}$ and mortality rate of birds at 21 and 39 days old. This is in agreement with the earlier studies (stated above) in which EOs had positive implications on growth rate of broiler chickens as in-feed agents. Most of these studies showed little difference in or improved FCR when EOs were fed to broilers, which partly agrees with the findings of the present study. What is particularly interesting about these studies, as well as the current experiment, is that there were still beneficial effects within the dataset as a whole (e.g. decreased pathogenic bacteria, increased oxidative stability, and improved immune response) which have not translated to significant improvement in FCR.

Many investigations have shown that dietary addition of plants the Labiate family and their essential oils of can positively affect chicken meat quality during refrigerated storage, an effect related to their antioxidant properties in the case of the reduction of lipid oxidation. Phytogenic compounds that were tested, which are mostly consisted of phenolic compounds, include rosemary and sage extracts (Lopez- Bote et al., 1998), oregano and oregano oil (Botsoglou et al., 2002; 2005), rosemary (Govaris et al., 2004), and rosemary and oregano oil (Basmacıoğlu et al., 2004; Botsoglou et al., 2005). However, there were no indications of significant beneficial effects of phytoadditive compounds on carcass yield and carcass cut-up parts yield (Alçiçek et al., 2004; Jamroz et al., 2005).

In the present experiment, significant contributions to meat quality from treatments supplemented with 24 and $48 \mathrm{mg} / \mathrm{kg}$ LEO were generated via increases of $L^{*}$ value and SOD activity in breast meat. This was fully in agreement with earlier research findings, which indicated that phenolic compounds of plants from the Labiate family improved the oxidative stability of poultry meat (Lopez-Bote et al., 1998; Botsoglou et al., 2002, 2005; Basmacıoğlu et al., 2004). The marked increase in $L^{*}$ value in chicken meat is closely related to total antioxidant capacity because of the relationship between brightness of meat ( $\mathrm{L}^{*}$ value) and phospholipase $A_{2}$ activity, an enzyme that oxidases phospholipids in meat (Soares et al., 2003).

Data obtained in the current experiment showed that LEO have an antioxidative effect in poultry meat, which had been screened for other EOs of the Labiate family. Collectively, this might serve as direct evidence for a lower need for antioxidant defence mechanism against lipid peroxidation in association with the antioxidant action of LEO with phenols as key constituents (i.e., camphor and tenchone in the present study).

The diets with 24 and $48 \mathrm{mg}$ LEO significantly reduced $(P<0.01)$ the percentage of liver weight of chickens compared with untreated ones (as seen in Table 4). This can be regarded as a remarkable regression within biological limits without any deterioration in general health status, performance and metabolic functions following the 39-day feeding period. With this in mind, the liver is an organ with a central metabolic role in the organism, which performs detoxification and antioxidation tasks (Džinic et al., 2015). The increased breast meat SOD concentration in birds fed LEO indicates that plant polyphenols have the capacity for powerful antioxidant activity. Thus, the phytogenic substances by LEO in the feed might alleviate the metabolic load of the liver among the proposed mechanism while enabling it to perform within less absolute weight.

The tendency to increase the proportional weight of the spleen, an organ with a significant role in the immune defence system, as a response to $48 \mathrm{mg} / \mathrm{kg}$ LEO supplementation, compared with the other treatments, is noticeable. Substantial evidence indicated that plant bioactives have positive implications on gut health and productive performance of poultry, and are generally recognized as safe (Yang et al., 2015; Franz et al., 2010). Nevertheless, the use of phytogenic compounds as animal feed additives may include potential side effects such as toxicity (Lambert et al., 2001; Cheng et al., 2014). Hence, as stated by Yang et al., (2015), a complete assessment of the toxicity and safety of phytogenic compounds is needed before the compounds can be used extensively in animal feeds.

\section{Conclusion}

From the data of the current experiment, LEO can be used successfully in broiler nutrition to increase bodyweight gain and could improve meat quality. Data obtained in this study and results from corresponding 
earlier experiments suggest that EOs of plants from the Labiate family, which consist mainly of phenols, when supplemented at levels of 24 to $48 \mathrm{mg} / \mathrm{kg}$ diet, are efficient in exerting antioxidant and growth promoter activity. It is worth investigating whether LEO has the potential to control liver pathologies of agricultural animals, in particular those caused by oxidative stress and mycotoxicosis, which is one of the popular topics on the agenda of animal feeding.

\section{Acknowledgement}

This project was supported by The Scientific and Technological Research Council of Turkey. Project No: TÜBiTAK-1919B011103032.

\section{Authors' Contributions}

$\mathrm{KK}$ and $\mathrm{MB}$ were in charge of project design. $\mathrm{KK}, \mathrm{ZK}, \mathrm{AA}{ }^{1}$ and $\mathrm{MC}$ were in charge of project implementation. $H A, A A^{3}$ and $F E G$ did the antioxidant enzyme measurements, $K K, Z K$. $A A^{1}$ and $M C$ did all the other analysis. $\mathrm{KK}, \mathrm{ZK}$ and $A A^{1}$ participated in results, statistics and interpretation of the study. KK wrote the manuscript. $M B$ and $Z K$ corrected the manuscript.

\section{Conflict of Interest Declaration}

The authors declare that they have no conflict of interest.

\section{References}

Aebi, H., 1983. Catalase. In: Bergmeyer, H.U. (ed.) Methods in enzymatic analysis. Academic Press. New York. 276286.

Alçiçek, A., Bozkurt, M. \& Çabuk, M., 2003. The effect of an essential oil combination derived from selected herbs growing wild in Turkey on broiler performance. S. Afr. J. Anim. Sci. 33, 89-94.

Alçiçek, A., Bozkurt, M. \& Çabuk, M., 2004. The effect of a mixture of herbal essential oils, an organic acid or a probiotic on broiler performance. S. Afr. J. Anim. Sci. 34, 217-222.

AOAC., 1990. Official methods of analysis (15th ed.), Association of Official Analytical Chemists. Washington, DC.

Aviagen., 2007. Broiler nutrition specifications. Aviagen Inc., Newbridge, Scotland, U.K.

Basmacıoğlu, H., Tokuşoğlu, Ö. \& Ergül, M., 2004. The effect of oregano and rosemary essential oils or alpha-tocopheryl acetate on performance and lipid oxidation of meat enriched with n-3 PUFAs in broilers. S. Afr. J. Sci. 34, 197210.

Basmacıoğlu, M.H., Baysal, Ş., Mısırlığlu, Z., Polat, M., Yilmaz, H. \& Turan, N., 2010. Effects of oregano essential oil with or without feed enzymes on growth performance, digestive enzyme, nutrient digestibility, lipid metabolism and immune response of broilers fed on a wheat-soybean meal diets. Br. Poult. Sci. 51, 67-80.

Botsoglou, N.A., Florou-Paneri, P., Christaki, E., Fletouris, D.J. \& Spais, A.B., 2002. Effect of dietary oregano essential oil on performance of chickens and on iron-induced lipid oxidation of breast, thigh and abdominal fat tissues. $\mathrm{Br}$. Poult. Sci. 43, 223-230.

Botsoglou, N.A., Christaki, E., Florou-Paneri, P., Giannenas, I., Papageorgiou, G. \& Spais, A.B., 2004. Effect of a mixture of herbal essential oils or a-tocopheryl acetate on performance parameters and oxidation of body lipid in broilers. S. Afr. J. Anim. Sci. 34, 52-61.

Botsoglou, N.A., Florou-Paneri, P., Botsoglou, E., Datos, V., Giannenas, I., Koidis, A. \& Mitrakos, P., 2005. The effect of feeding rosemary, oregano, safran and $\infty$-tocopheryl acetate on hen performance and oxidative stability of eggs. S. Afr. J. Anim. Sci. 35, 143-151.

Bozkurt, M., Küçükyılmaz, K., Çatlı, A.U. \& Çınar, M., 2009. Effect of dietary mannan oligosaccharide with or without oregano essential oil and hop exctrat supplementation on the performance and slaughter characteristics of male broilers. S. Afr. J. Anim. Sci. 39 (3), 223-232.

Bozkurt, M., Küçükyılmaz, K., Çatı, A.U., Özyıldız, Z., Çınar, M., Çabuk, M. \& Çöven, F., 2012a. Influences of an essential oil mixture supplementation to corn versus wheat-based practical diets on growth, organ size, intestinal morphology and immune response of male and female broilers. Ital. J. Anim. Sci. 11, 290-297.

Bozkurt, M., Selek, N., Küçükyılmaz, K., Eren, H., Güven, E., Çatı, A.U. \& Çınar, M., 2012b. Effects of dietary supplementation with a herbal extract on performance of broilers infected with a mixture of Eimeria species. Br. Poult. Sci. 53, 325-332.

Brenes, A. \& Roura, E., 2010 Essential oils in poultry nutrition: Main effects and modes of action. Anim. Feed Sci. Technol. 158, 1-14.

Castellini, C., Mugnai, C. \& Dal Bosco, A., 2002. Effect of organic production system on broiler carcass and meat quality. Meat Sci. 60, 219-225.

Cavanagh, H.M.A. \& Wilkinson, J. M., 2002. Biological activities of lavender essential oil. Phytother. Res. 16, 301-308.

Cheng, G., Hao, H., Xie, S., Wang, X., Dai, M., Huang, L. \& Yuan, Z., 2014. Antibiotic alternatives: The substitution of antibiotics in animal husbandry, Front. Microbiol. 5, 217.

Dang, M.N., Takácsová, M., Nguyen, D.V. \& Kristiánová, K., 2001. Antioxidant activity of essential oils from various spices. Nahrung/Food. 45(1), 64-66.

Durak, I., Yurtarslani, Z., Canbolat, O. \& Akyol, O., 1993. A methodological approach to superoxide dismutase (SOD) activity assay based on inhibition of nitroblue tetrazolium (NBT) reduction. Clin. Chim. Acta. 31, 103-104. 
Dzinic, N., Puvaca N., Tasic, T., Ikonic, P. \& Okanovic, Đ., 2015. How meat quality and sensory perception are influenced by feeding poultry plant extracts. World's Poult. Sci. J. 71, 673-682.

Economou, H. D., Orepoulou, V. \& Thomopoulos, C., 1991. Antioxidant properties of some plant extracts of the Labiatae family. J. Am. Oil Chem. Soc. 68, 109-113.

Fanatico, A.C., Cavitt, L.C., Pillai, P.B., Emmert, J.L. \& Owens, C.M., 2005. Evaluation of slow growing broiler genotypes grown with and without outdoor access: Meat quality. Poult Sci. 84, 1785-1790.

Franz, C., Baser, K.H.C. \& Windsch, W., 2010. Essential oils and aromatic plants in animal feeding - a European perspective. A review. Flavour Fragr. J. 25, 327-340.

Govaris, A., Botsoglou, N., Papageorgiou, G., Botsoglou, E. \& Ambrosiadis, I., 2004. Dietary versus post-mortem use of oregano oil and/or a-tocopherol in turkeys to inhibit development of lipid oxidation in meat during refrigerated storage. Int. J. Food Sci. Nutr. 55, 115-23.

Gülçin, İ., Şat, İ.G., Beydemir, Ş., Elmestaş, M. \& Küfrevioğlu, Ö.İ., 2004. Comparison of antioxidant activity of clove (Eugenia caryophylata Thunb) buds and lavender (Lavandula stoechas L.). Food Chem. 87, 393-400.

Halliwell, B. \& S. Chirico., 1993. Lipid oxidation: its mechanism, measurement and significance. Am. J. Clin. Nutr. 57, 724S-725S.

Hernandez, F., Madrid, J., Garcia, V., Orengo, J., Megias, M.D., 2004. Influence of two plant extracts on broiler performance, digestibility, and digestive organ size. Poult. Sci. 83, 169-174.

Jamroz, D., Wiliczkiewicz, A., Wertelecki, T., Orda, J. \& Sukorupinska J., 2005. Use of active substances of plant origin in chicken diets based on maize and locally grown cereals. Br Poult Sci., 46, 485-493.

Jang, I.S., Ko, Y. H., Kang, S.Y. \& Lee, C. Y., 2007. Effect of a commercial essential oil on growth performance, digestive enzyme activity and intestinal microflora population in broiler chickens. Anim. Feed Sci. Tech. 134, 304315.

Lambert R.J.W., Skandamis P.N., Coote P.J. \& Nychas G.J.E., 2001. A study of the minimum inhibitory concentration and mode of action of oregano essential oil, thymol and carvacrol. Appl. Microbiol. 91, 453-462.

Lopez-Bote, L.J., Gray, J.I., Gomaa, E.A. \& Flegal, C.I., 1998. Effect of dietary administration of oil extracts from rosemary and sage on lipid oxidation in broiler meat. Br. Poult. Sci. 39, 235-240.

Lowry, O.H, Rosebrough, N.J. \& Farr, A.L., 1951. Protein measurement with the Folin phenol reagent. J. Biol. Chem. 193, 265-275.

Öztürk, B., Konyalıoğlu, S., Kantarcı, G. \& Çetinkol, D., 2005. Essential oil composition antibacterial antifungal and antioxidant capacity of wild L. Subsp. Stoechas., Izmir, Anadolu.15 (1), 61-72.

SAS Institute. 2001. SAS User's Guide. Version 8 ed. SAS Institute Inc. Cary, NC.

Soares, A. L., Ida, E. I., Miyamoto, S., Hernandez-Blazquez, F., Olivo, J., Pinheiro R. J.W. \& Phospolipase, M.S., 2003. A2 Activity in poultry pale, soft, exudative (PSE) meat. J. Food Biochem. 27, (4), 309-320.

Steiner, T., 2009. Phytogenics in animal nutrition. Nottingham University Press., ISBN 978-1-904761-71-6.

Sun, Y., Oberley, L.W. \& Li, Y., 1988. A simple method for clinical assay of superoxide dismutase. Clin. Chem. 34, $497-$ 500.

TSE, 1991. Animal feed-determination of metabolizable energy (chemical method). Turkish Standards Institute. Publ. No. 9610, 1-32.

Yang, C., Kabir C. M. A., Yongqing, H. \& Joshua G., 2015. Phytogenic compounds as alternatives to in-feed antibiotics: Potentials and challenges in application. Pathogens. 4, 137-156.

Yoshoiko, T., Kawada, K. \& Shimada, T., 1979. Lipid peroxidation in maternal and cord blood and protective mechanism against active-oxygen toxicity in the blood. Am. J. Obstet. Gynecol. 135, 372-376.

Zeng, Z., Sai Z., Hongliang W. \& Xiangshu P., 2015. Essential oil and aromatic plants as feed additives in non-ruminant nutrition: A review. J. Anim. Sci. Biotechnol. 6:7. 